\title{
Activity of Naturally Derived Antimicrobial Peptides against Filamentous Fungi Relevant for Agriculture
}

\author{
Patricia Larrañaga ${ }^{1}$, Paola Díaz-Dellavalle ${ }^{1}$, Andrea Cabrera ${ }^{1}$, Diego Alem ${ }^{1}$, Carolina Leoni ${ }^{2}$, André Luis \\ Almeida Souza ${ }^{3}$, Salvatore Giovanni-De-Simone ${ }^{3,4} \&$ Marco Dalla-Rizza $^{1}$ \\ ${ }^{1}$ Laboratorio de Proteínas, Unidad de Biotecnología, Estación Experimental Wilson Ferreira Aldunate, Instituto \\ Nacional de Investigación Agropecuaria (INIA Las Brujas), Uruguay \\ ${ }^{2}$ Departamento de Protección Vegetal, Programa Nacional de Investigación de Producción y Sustentabilidad \\ Ambiental, Estación Experimental Wilson Ferreira Aldunate, Instituto Nacional de Investigación Agropecuaria \\ (INIA Las Brujas), Uruguay \\ ${ }^{3}$ Laboratory of Protein and Peptides Biochemistry, Oswaldo Cruz Institute, Rio de Janeiro, RJ \\ ${ }^{4}$ National Institute of Science and Technology on Innovation on Neglected Diseases (INCT-IDN)/Center for \\ Technological Development in Health (CDTS), FIOCRUZ \\ Correspondence: Marco Dalla-Rizza, Laboratorio de Proteínas, Unidad de Biotecnología. Estación Experimental \\ Wilson Ferreira Aldunate, Instituto Nacional de Investigación Agropecuaria (INIA), Uruguay. Tel: 598-367-7701. \\ E-mail: mdallarizza@inia.org.uy
}

Received: June 12, 2012 Accepted: July 10, 2012 Online Published: July 23, 2012

doi:10.5539/sar.v1n2p211

URL: http://dx.doi.org/10.5539/sar.v1n2p211

\begin{abstract}
The search for environmentally biocompatible and cost-effective methods to control filamentous fungi in agriculture is becoming increasingly urgent. In vitro antimicrobial activity of three synthetic peptides was investigated against some filamentous fungi with agricultural relevance. The peptides were an analog of Temporin called Temporizina, a fragment from Pleurocidin termed Plc-2, and a peptide identified from sesame seeds named Pses3. Antimicrobial activity of these peptides towards filamentous fungi has not been previously reported. Seven plant pathogenic or mycotoxigenic fungal species, isolated from plant tissues were assayed: Alternaria solani, Colletotrichum gloesporioides, Fulvia fulvum, Fusarium oxisporum, Aspergillus niger, A. ochraceus and Penicillium digitatum. Values of Minimum Inhibitory Concentration (MIC) and Minimum Fungicidal Concentration (MFC) were determined and compared with the commercially available fungicide Captan as a positive control. The peptides showing greatest inhibition were Pses3 and Plc-2 and $C$. gloesporioides was the most sensitive of the evaluated fungi. The MIC values for Plc-2 and Pses3 peptides ranged from $0.64 \mu \mathrm{M}$ to $10.25 \mu \mathrm{M}$. These values were much lower than those observed for Captan, suggesting the potential of these peptides as fungicides. In particular, Pses3 is a novel peptide derived from sesame seeds not reported in databases.
\end{abstract}

Keywords: antimicrobial peptides, temporizina, Plc-2, Pses3, antifungal activity

\section{Introduction}

Global losses in agriculture have been estimated of around 35\% of annual production due to abiotic and biotic factors (Agrios, 2004). Among the biotic factors, phytopathogenic fungi are the major infectious agents in plants, producing disease and/or substances toxic to human health. Currently, the most effective and widely method to manage plant fungal diseases and to prevent food spoilage with mycotoxins involves chemically-derived fungicide application. The use of fungicides, however, is also associated with limitations such as nonspecific toxicity, emergence of resistance in the fungal population, and limited spectrum of action. In addition, changes in regulatory standards for residue control in food products increasingly requires lower levels of products used to control pathogens, with lower intrinsic toxicity and reduced environmental impact (EFSA, 2010). Importing markets and consumers are increasingly demanding lower levels of pesticides in agricultural products produced following sustainable practices. Tighter regulations have led to some pesticides being banned, and disease management of economically important plants has become more difficult because of the lack of effectiveness of available compounds (Montesinos et al., 2007). 
Antimicrobial peptides (AMPs) have been found in virtually all organisms, including prokaryotes and eukaryotes, e.g., mammals, amphibians, insects and plants (Bulet et al., 2004). AMPs are evolutionarily conserved components of the innate immune response and are primary effector molecules (Téllez \& Castaño, 2010). The spectrum of activity of various antimicrobial peptides is very broad including antiviral, antifungal and antibacterial activities and, in some cases, anti-tumor and immunomodulatory properties. Most AMPs are cationic, and thus have a positive charge at physiological $\mathrm{pH}$; they are frequently smaller than 100 amino acid residues, and adopt amphipathic structures enabling them to interact with membranes, part of their mechanism of action (Hancock \& Sahl, 2006; Marcos et al., 2008).

Different mechanisms have been described for various AMPs allowing for a detailed understanding of their modes of action. Many researchers highlight membrane insertion and association of the peptides into ion-permeable pores leading to the disruption of the cell membrane, but non-lytic mode of action have also been reported (Muñoz \& Marcos, 2006). It is known that peptides may interact at three levels: with the outer microbial structures, with the cell membrane and finally with intracellular targets (Marcos \& Gandía, 2009). Electrostatic interaction between the plasma membrane and the cationic peptides has been highlighted in all the models so far proposed for the various modes of action of AMPs (Badosa et al., 2009). Marcos and Gandía (2009) suggested that one AMP might combine different killing mechanisms, which potentiate antimicrobial activity and diminishes the risk of developing resistance in the susceptible microbes. At the cellular level, in both microorganisms and higher organisms, qualitative and quantitative differences in the structural composition of cell wall and membrane could explain the effects of the peptides (Table 1).

Table 1. Structural components of cell walls or cell membranes of different classes of organisms (Source: prepared by the Authors based on published information).

\begin{tabular}{|c|c|c|c|c|c|c|}
\hline & \multicolumn{3}{|c|}{ PRINCIPAL CELL WALL COMPONENTS } & \multicolumn{3}{|c|}{$\begin{array}{c}\text { PRINCIPAL CELL } \\
\text { MEMBRANE COMPONENTS } \\
\end{array}$} \\
\hline & Lipids & Protein & Polysaccharides & Lipids & Protein & $\begin{array}{c}\text { Net } \\
\text { charge }\end{array}$ \\
\hline $\begin{array}{c}\text { GRAM-POSITIVE } \\
\text { BACTERIA } \\
\text { Prokaryote } \\
\text { Cell type }\end{array}$ & Lipoteichoic acid & $\begin{array}{l}\text { Mostly lipoproteins } \\
\text { and porins }\end{array}$ & $\begin{array}{l}90 \% \text { peptidoglycan, } \\
\text { Teichoic Acid }\end{array}$ & $\begin{array}{l}\text { 18\% phosphatidylglycerol: } \\
\text { anionic Glycerol } \\
\text { 65\% Phosphatidylethanolami } \\
\text { ne: Ethanolamine-neutral. } \\
\text { Phosphatidylserine } \\
\text { Traces:Serine-anionic. }\end{array}$ & $\begin{array}{l}50 \% \\
\text { variable } \\
\text { according } \\
\text { to the } \\
\text { media }\end{array}$ & Negative \\
\hline $\begin{array}{c}\text { GRAM-NEGATIVE } \\
\text { BACTERIA } \\
\text { Prokaryote } \\
\text { Cell type }\end{array}$ & $\begin{array}{c}\text { Lipopolysaccharide- } \\
\text { LPS, }\end{array}$ & $\begin{array}{l}\text { Mostly lipoproteins } \\
\text { and porins. }\end{array}$ & $10 \%$ peptidoglycan. & $\begin{array}{l}\text { 18\% phosphatidylglycerol } \\
\text { anionic Glycerol } \\
\text { 65\% Phosphatidylethanolami } \\
\text { ne: } \\
\text { Ethanolamine-neutral. Phosp } \\
\text { hatidylserine Traces: } \\
\text { Serine-anionic. }\end{array}$ & $\begin{array}{l}50 \% \\
\text { variable } \\
\text { according } \\
\text { to the } \\
\text { media }\end{array}$ & Negative \\
\hline $\begin{array}{c}\text { FILAMENTOUS } \\
\text { FUNGI } \\
\text { Eukaryotic } \\
\text { Cell type }\end{array}$ & Absent & $\begin{array}{l}20-30 \% \text { dry weight } \\
\text { mannoproteins }\end{array}$ & $\begin{array}{c}50-60 \% \text { dry } \\
\text { weight glucans, } \\
\beta-1,3, \beta-1,6, \alpha-1,3 \\
\text { D-glucans,galactomannan } \\
\text { and mannan } 10-20 \% \text { dry } \\
\text { weight of chitin }\end{array}$ & $\begin{array}{c}\text { Sphingolipids: } \\
\text { Sphingosine + fatty acid: } \\
\text { Mannosyl-di-inositol } \\
\text { phosphate-ceramide. } \\
\text { Sterols: Mostly Ergosterol. }\end{array}$ & $\begin{array}{l}50 \% \\
\text { variable } \\
\text { according } \\
\text { to the } \\
\text { media }\end{array}$ & Negative \\
\hline $\begin{array}{l}\text { YEAST } \\
\text { Eukaryotic } \\
\text { Cell type }\end{array}$ & Absent & $\begin{array}{l}30-50 \% \text { dry weight } \\
\text { mannoproteins }\end{array}$ & $\begin{array}{l}1-2 \% \text { dry weight glucans, } \\
\beta-1,3-\beta-1,6-\mathrm{D} \text {-glucans } \\
\text { galactomannan and } \\
\text { mannan } \\
2 \% \text { dry weight of chitin }\end{array}$ & $\begin{array}{l}\text { Sphingolipids: } \\
\text { Sphingosine + fatty acid: } \\
\text { Mannosyl-di-inositol } \\
\text { phosphate-ceramide. } \\
\text { Sterols: Mostly Ergosterol }\end{array}$ & $\begin{array}{l}50 \% \\
\text { variable } \\
\text { according } \\
\text { to the } \\
\text { media }\end{array}$ & Negative \\
\hline $\begin{array}{l}\text { PLANT CELL } \\
\text { Eukaryotic } \\
\text { Cell type }\end{array}$ & Absent & $\begin{array}{l}\text { HRGPs rich hydroxyproline } \\
\text { Protein-PRPs } \\
\text { Proline-rich proteins GRPs: } \\
\text { Rich in glycine proteins and } \\
\text { AGPs, arabinogalactan } \\
\text { proteins. }\end{array}$ & $\begin{array}{c}\text { Cellulose } 20-40 \% \\
\beta 1-4 \text { glucose polymers. }\end{array}$ & Mostly Phytosterols & $\begin{array}{l}20-70 \% \\
\text { varies } \\
\text { depending } \\
\text { on cell } \\
\text { type. }\end{array}$ & $\begin{array}{l}\text { No net } \\
\text { charge }\end{array}$ \\
\hline $\begin{array}{l}\text { ANIMAL CELL } \\
\text { Eukaryotic } \\
\text { Cell type }\end{array}$ & & Absence of cell wall & & $\begin{array}{c}\text { 7-15\% Phosphatidylethanola } \\
\text { mine: } \\
\text { Ethanolamine-neutral. } \\
\text { 10-25\% Phosphatidylethano } \\
\text { lamine: } \\
\text { 10\% Phosphatidylserine: } \\
\text { Serine-anionic. } \\
\text { Sterols: } 25 \% \text { cholesterol. }\end{array}$ & $\begin{array}{l}20-70 \% \\
\text { varies } \\
\text { depending } \\
\text { on cell } \\
\text { type. }\end{array}$ & $\begin{array}{l}\text { No net } \\
\text { charge }\end{array}$ \\
\hline
\end{tabular}


Currently, several well characterized natural peptides and derivatives are known to have antimicrobial properties (Hammami et al., 2009; Pelegrini et al., 2011). Among them, Temporins are relatively small AMPs (10 to 14 amino acids) found in skin secretions of amphibians (Ghiselli et al., 2002; Mangoni et al., 2006), that have net positive charge at neutral $\mathrm{pH}$, and an amidated $\mathrm{C}$-terminus. This family of peptides includes more than 40 members showing antimicrobial activity against a broad range of pathogens including Gram positive and negative bacteria and yeasts, but are not toxic to mammalian cells. Temporins adopt amphipathic $\alpha$-helical conformations in hydrophobic solvents that play an important role in their mechanism of action (Conlon et al., 2004), which is thought to involve disruption of the plasma membrane (Oren et al., 1999). In this study, a 14 amino-acid fragment named Temporizina, was synthesized and rationally designed by the Laboratory of Biochemistry of Proteins and Peptides of the IOC/FIOCRUZ-RJ-Brazil, based on the sequence of three antimicrobial peptides (Souza, 2012) (Table 2).

Plc-2 is a small C-terminal peptide of 11 amino acids derived from Pleurocidin, a linear peptide isolated from the fish Pleuronectes americanus (Table 2), also known as flounder or winter flounder (Cole et al., 1997; Souza et al., 2012). This fragment is a cationic peptide with $\alpha$-helical structure and has antimicrobial activity against Gram positive and negative bacteria and yeast. It is particularly effective against human pathogens that are usually resistant to traditional antibiotic treatments, and it shows a high percentage ( $>91 \%)$ of lytic activity on $P$. aeruginosa, moderate on $S$. aureus and E. coli but no effect on E. faecalis and M. tuberculosis growth.

Pses3 is a synthetic fragment of 20 amino acids derived from cationic peptides of sesame kernel (Table 2). Sesame (Sesamum indicum L.) is an oleaginous kernel that has been commonly used by several nations as a source of food and medicines. Previous studies have reported the presence of antimicrobial cationic peptides from $S$. indicum kernels of black and white cultivars with activity against human pathogens (Teles et al., 2007).

Table 2. Structural parameters and properties of Plc-2, Temporizina and Pses3

\begin{tabular}{|c|c|c|c|}
\hline & \multicolumn{3}{|c|}{ Peptide } \\
\hline & Plc-2 & Temporizina & Pses3 \\
\hline Sequence & KHVGKAALTHY & LWLWLWLW & RYYRYVHGYMGPKGYTR \\
\hline Molecular weight $(\mathrm{g} / \mathrm{mol})$ & 1224.4 & 1942.4 & 2638 \\
\hline Theorical pI & 9.7 & 10 & 10.28 \\
\hline Number of residues & 11 & 14 & 20 \\
\hline Net charge $\mathrm{z}$ & $(+) 2$ & $(+) 2$ & $(+) 5$ \\
\hline Charged residues & 2 ,Lys & 2 ,Lys & 4Arg, 1Lys \\
\hline Uncharged residues + GLY & 1Gly ,1Thr ,2His & 0 , Gly & 3Gly ,1Thr 1His , 1 Gln \\
\hline Aromatic residues & $1 \mathrm{Tyr}$ & $1 \mathrm{Phe}, 4 \operatorname{Trp}$ & $1 \operatorname{Trp} 5 \mathrm{Tyr}$ \\
\hline Polar residues + GLY $(\mathrm{n} / \%)$ & $6 / 55.54$ & $2 / 14.29$ & $11 / 55,00$ \\
\hline $\begin{array}{l}\text { Nonpolar residues } \\
\quad(\mathrm{n} / \%)\end{array}$ & $5 / 45.45$ & $12 / 85.71$ & $9 / 45.00$ \\
\hline Aliphatic index & 80 & 167.14 & 14.5 \\
\hline $\begin{array}{c}\text { Mean relative } \mu \mathrm{Hrelb} \text { moment } \\
\text { CCS }\end{array}$ & 0.29 & 0.16 & 0.16 \\
\hline Mean H moment CCS & -1.77 & 6.21 & -2.0 \\
\hline Hydropathicity (GRAVY) & -0.455 & -0.90 & -1.670 \\
\hline Instability index & 33.66 & 105.01 & 9.11 \\
\hline
\end{tabular}


Online ExPASy Proteomic server: HYPERLINK http://ca.expasy.org. http://heliquest.ipmc.cnrs.fr/cgi-bin/ComputParams.py and the Antimicrobial Sequences Database and Software: http://www.bbcm.units.it/. HydroMCalc. The relative hydrophobic moment ( $\mu$ Hrel for short) of a peptide is its hydrophobic moment relative to that of a perfectly amphipathic peptide. A value of 0.5 indicates that the peptide has about $50 \%$ of the maximum possible amphipathicity. The mean hydrophobicity ( $\mathrm{H}$ for short) calculated by CCS scale is the total hydrophobicity (sum of all residue hydrophobicity indices) divided by the number of residues (with alpha helix projection angle $100^{\circ}$ ). (Giangaspero et al., 2001).

All peptides used in this work (Temporizina, Plc-2 and Pses3) were rationally designed and produced by the Laboratory of Biochemistry of Proteins and Peptides, FIOCRUZ, (Brazil, see De Simone \& Souza, 2002).

The aim of the present study was to evaluate the in vitro antifungal activity of three synthetic peptides, derived from natural sources, against seven filamentous fungi with agricultural relevance. The effect of the synthetic peptides on cell permeation of filamentous fungal was evaluated by in vitro bioassay and fluorescence microscopy.

\section{Materials and Methods}

\subsection{Synthetic Peptides}

Temporizina, Plc-2 and Pses3 were designed and produced by the Laboratory of Biochemistry of Proteins and Peptides, FIOCRUZ, (Brazil). Peptides were synthesized by the solid-phase synthesis method on a PSS-8 (Shimadzu, Kyoto, Japan) Pepsynthesizer according to fluoren-9-methyloxycarbonyl (Fmoc)-polyamide active ester chemistry. Amino acids for peptide synthesis were from Calbiochem-Novabiochem Corp. (Germany).

For the assay, the peptide concentrations ranged from 2-fold serial dilutions. The initial concentrations were 1 $\mathrm{mgml}^{-1}$ for each peptides (10X working peptides solutions). As a positive control the fungicide Captan was used at $0.5 \mathrm{mgml}^{-1}$ (Molecular Weight 300.61).

\subsection{Phylamentous Fungi}

Seven phylamentous fungi were used in the experiments: Alternaria solani, Colletotrichum gloesporioides, Fulvia fulvum, Fusarium oxisporum, Aspergillus niger and A. ochraceus (kindly provided by the Department of Plant Protection, INIA Las Brujas, Uruguay, Table 3) and Penicillium digitatum (strain A35, kindly provided by the Department of Plant Pathology, INIA Salto Grande, Uruguay). The fungal isolates were maintained in PDA slants at $4^{\circ} \mathrm{C}$ till use. Spores of each fungus were obtained from cultures on agar plates (Potato Dextrose Agar (PDA), Oxoid, Hampshire, U.K.) after 7 days at $27^{\circ} \mathrm{C}$ as described previously (Broekaert et al., 1990). The concentration of the spore suspension was determined using a Thoma-Neubauer cell counting chamber (BOECO, Hamburg, Germany), and suspensions were adjusted to $2 \times 10^{6}$ sporesml $^{-1}$.

Table 3. Phylamentous fungi used in the experiments detailing original plant tissue species and source

\begin{tabular}{llll}
\hline Fungal species & Isolate code & Origin & Source \\
\hline Alterrnaria solani & HBX & Tomato & INIA LB Plant Pathology Lab \\
$\begin{array}{l}\text { Colletotrichum gloesporioides } \\
\text { Fulvia fulvum }\end{array}$ & CC1 & Strawberry (crown) & INIA LB Plant Pathology Lab \\
$\begin{array}{l}\text { Fusarium oxysporum } \\
\text { f.sp. lycopersici }\end{array}$ & STM & Tomato (leaves) & INIA LB Plant Pathology Lab \\
$\begin{array}{l}\text { Aspergillus niger } \\
\text { A. } \text { ochraceus }\end{array}$ & EOA & Tomato (stem) & INIA LB Plant Pathology Lab \\
Penicillium digitatum & RS3 & Grape & Dr. Ramos Girona, Lleida \\
\hline & RN8 & Grape & Dr. Ramos Girona, Lleida \\
\hline
\end{tabular}

\subsection{Determination of Antifungal Activity and MIC}

The assay for microbial growth was performed on 96-well sterile microtiter plates (Nunc, Roskilde, Denmark) by a quantitative microspectrophotometric method (Broekaert et al., 1990). The final volume per well was 200 $\mu \mathrm{L}$. Firstly, $20 \mu \mathrm{L}$ of $10 \mathrm{X}$ working peptides solutions were dispensed added in the first column of a microplate. Each row consisted of a serial dilution series for a given peptide. For each well, $180 \mu \mathrm{L}$ of a spore suspension of 
each fungus $\left(2 \times 10^{6}\right.$ sporesml $^{-1}$ in fresh PDB, Potato Dextrose Broth, Himedia, India at $\left.70 \%\right)$ were added to 20 $\mu \mathrm{L}$ serial dilution of peptide. In one row $20 \mu \mathrm{L}$ of sterile distilled water was used instead of peptide, to check for fungal growth without any inhibition. The commercial fungicide Captan, $0.5 \mathrm{mgml}^{-1}$ (Ftalimida, wettable powder), was used to check fungal growth inhibition as a positive control (Satish et al., 2007). The plates were incubated at the appropriate temperature for each organism in an oven, without agitation. Fungal growth was measured after $48 \mathrm{~h}$ of incubation and OD at $595 \mathrm{~nm}$ (Díaz-Dellavalle et al. 2011) determined in a Multiskan Spectrum plate spectrophotometer (Thermo Electron Corporation, Finland). For each fungal assay, three replications by treatment and concentration were done. The Minimum Inhibitory Concentration (MIC) was defined as the concentration of peptides $(\mu \mathrm{M})$ that caused $90 \%$ growth inhibition compared with negative controls-the medium without any treatment- after 48 hours. MIC was calculated with the average of the replications.

\subsection{Determination of Minimum Fungicide Concentration (MFC)}

The in vitro fungicidal activity (MFC) was determined as described by Díaz-Dellavalle et al. 2011. For MFC determination we used a subsample collected from the microplates previously incubated for $72 \mathrm{hs}$ for fungal development in media broth amended with the challenged AMP. The subsample was collected from the first wells with no visible growth of the fungi, and was transferred into PDA for a new incubation at $27^{\circ} \mathrm{C}$. A positive control (subsample from media broth with water) was also incubated on PDA. For all plates, incubation lasted till fungal growth was observed on control plates. After $72 \mathrm{~h}$ of incubation, $20 \mu \mathrm{L}$ was subcultured from each well that showed no visible growth (growth inhibition greater than 98\%), from the last positive well (growth similar to that for the growth control well), and from the growth control (peptide-free medium) onto PDA plates. The plates were incubated at $27^{\circ} \mathrm{C}$ until growth was seen in the growth control subculture. The minimum fungicidal concentration was regarded as the lowest peptide concentration $(\mu \mathrm{M})$ that did not yield any fungal growth on the solid medium used. For each fungal isolate, three replications by treatment and concentration were done. MFC was calculated with the average of the replications.

\subsection{Evaluation of the Permeability of Fungal Plasma Membrane}

In order to detect cell lysis, the permeability of the plasma membrane was visualized by fluorescence microscopy using the probe Sytox Green (SG, Invitrogen, USA), which is unable to cross intact biological membranes (Muñoz \& Marcos, 2006). To view the fungal structures we simultaneously used the fluorophore Calcofluor White (CW, Sigma-Aldrich, USA) which has high affinity for the chitin in fungal cell walls. Ten $\mu \mathrm{L}$ per well of a stock solution of SG (4 $\mu \mathrm{M}$ in $5 \%$ PDB) to a final concentration of $0.2 \mu \mathrm{M}$ was added to each fungal sample previously exposed to the peptides at different concentrations for at least 48 hours, and then incubated for 5 min in the dark. Five $\mu \mathrm{L}$ of $\mathrm{CW} 0.1 \%\left(\mathrm{w} / \mathrm{v}\right.$ ) was added to a final concentration of $50 \mu \mathrm{gml}^{-1}$. Finally, samples were incubated for $5 \mathrm{~min}$ in the dark, washed and mounted on slides in a solution of $20 \%$ glycerol. The washing protocol was optimized for each fungus, taking into consideration the macroscopic characteristics of its mycelium, strength, quantity, pigmentation and sporulation rate. In general, mycelia were washed twice, and then harvested by centrifugation after incubation with the probes. Microscopic visualization of the samples was done using a vertical optical photomicroscope, Optiphot-2 (Nikon Corporation, Japan) with an epifluorescence system, a mercury light source $(100 \mathrm{~W})$ and filters to visualize SG after excitation at $488 \mathrm{~nm}$ and $\mathrm{CW}$ after excitation at $355 \mathrm{~nm}$. Photographs were taken with a digital camera, COOLPIX S10 VR, 6.0 megapixels with a 10x zoom and with a microscope adapter (Nikon Corporation, Japan).

\section{Results and Discussio}

Table 4. MIC and MFC in $\mu \mathrm{M}$ observed in seven filamentous fungal pathogens.

\begin{tabular}{lccccccccccccccc}
\hline \multicolumn{11}{c}{ MIC and MFC $\mu \mathrm{M}$} \\
\hline \multicolumn{11}{c}{ A. solani } & \multicolumn{11}{c}{ C. gloesporioides } & F. fulvum & F. oxysporum & P. digitatum & A. niger & A. ochraceus \\
PEPTIDE & MIC & MFC & MIC & MFC & MIC & MFC & MIC & MFC & MIC & MFC & MIC & MFC & MIC & MFC \\
Plc-2 & 2,56 & Nd & 0,64 & 2,56 & 5,12 & 20,5 & 2,56 & 5,12 & 2,56 & Nd & 1,28 & 2,56 & 10,25 & $>20,5$ \\
Pses3 & 2,37 & 2,37 & 1,18 & 2,37 & 4,75 & $>19$ & 1,18 & 2,37 & 2.37 & Nd & 2,37 & 4,75 & $>19$ & $>19$ \\
Captan & 41,6 & Nd & 5,2 & Nd & 10,4 & Nd & 5.2 & Nd & 1.3 & Nd & 5.2 & Nd & $5, .2$ & Nd \\
\hline
\end{tabular}

* MIC and MFC were not determined for Temporizina because only values above $90 \%$ inhibition were considered for subsequent determination of these parameters. MIC and MIF were calculated with the average of three replications. Nd: Not determined. 
As shown in Table 4 and Figures 1, 2 and 3, the growth inhibition of the tested fungi varied depending on the species treated with the different peptides. In general, for the seven fungi evaluated, Pses 3 and Pcl-2 were the most active peptides, producing complete growth inhibition. Temporizina, which had a lower overall activity, was significantly active against Alternaria solani, Penicillium digitatum and Fulvia fulvum with growth inhibition higher than 50\% compared with other species of fungi treated (Figure 3). In our conditions, high inhibition values (>90\%) were used to estimate MIC and MFC. Interestingly, MIC values obtained for Plc-2 and Pses3 were lower than those for the commercial fungicide Captan when tested on five of the seven fungi species we studied (see Table 4, Figure 1, 2 and 3).

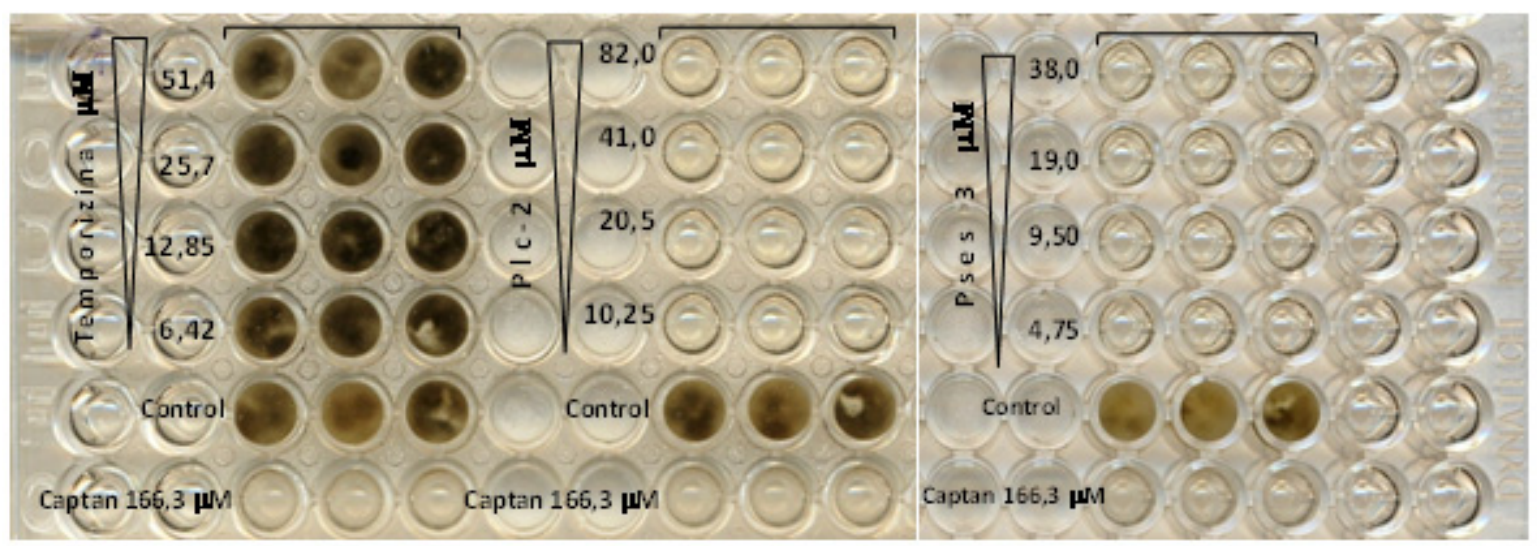

Figure 1. Microplate biosssay showing the effect of the three AMPs on the fungal growth of Alternaria solani after incubation for $48 \mathrm{hs}$ at $27^{\circ} \mathrm{C}$. For each AMP, four peptide concentrations (in $\mu \mathrm{M}$ ) are compared with the synthetic fungicide Captan (positive control) and water (negative control).
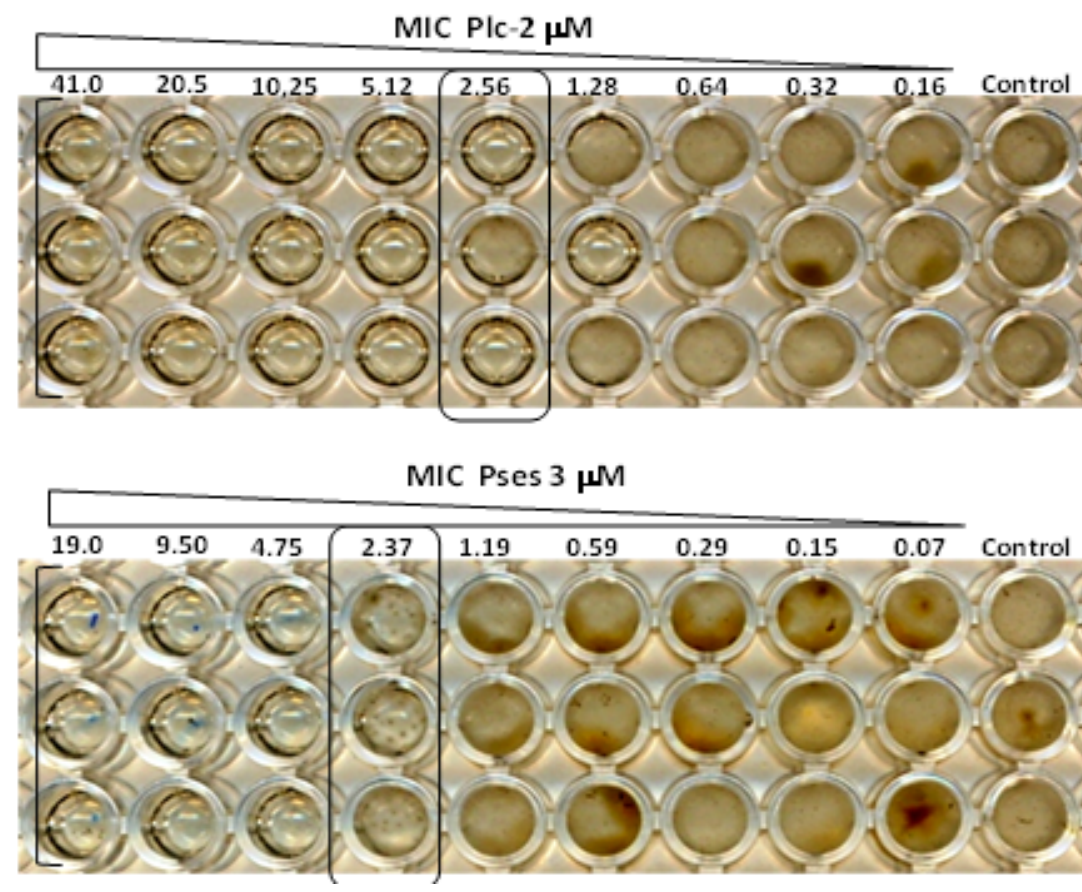

Figure 2. Microplate bioassay for MIC $(\mu \mathrm{M})$ determination of the AMPs Plc-2 and Pses3 for Alternaria solani. The numbers in the figure indicate the AMP concentration in $\mu \mathrm{M}$, and the Control is the media broth with water. The rectangle indicates the established MIC.

When the susceptibility of the filamentous fungi was compared, the most tolerant were $A$. ochraceus and $F$. fulvum. Among fungi, the values of MFC varied 32-fold for Plc-2 and 16-fold for Pses3. This observation is 
especially significant showing that there are compositional differences in the cell wall, membrane constituents and beyond the membrane among fungi that explain a differential response to peptides (Table 1). In this regard, we must remember that these peptides were initially selected for their antibacterial activity. In general, for most of the fungi tested good inhibitory values were obtained with the peptides Plc-2 and Pses3 (Table 4 and Figure 1, $2,3)$.
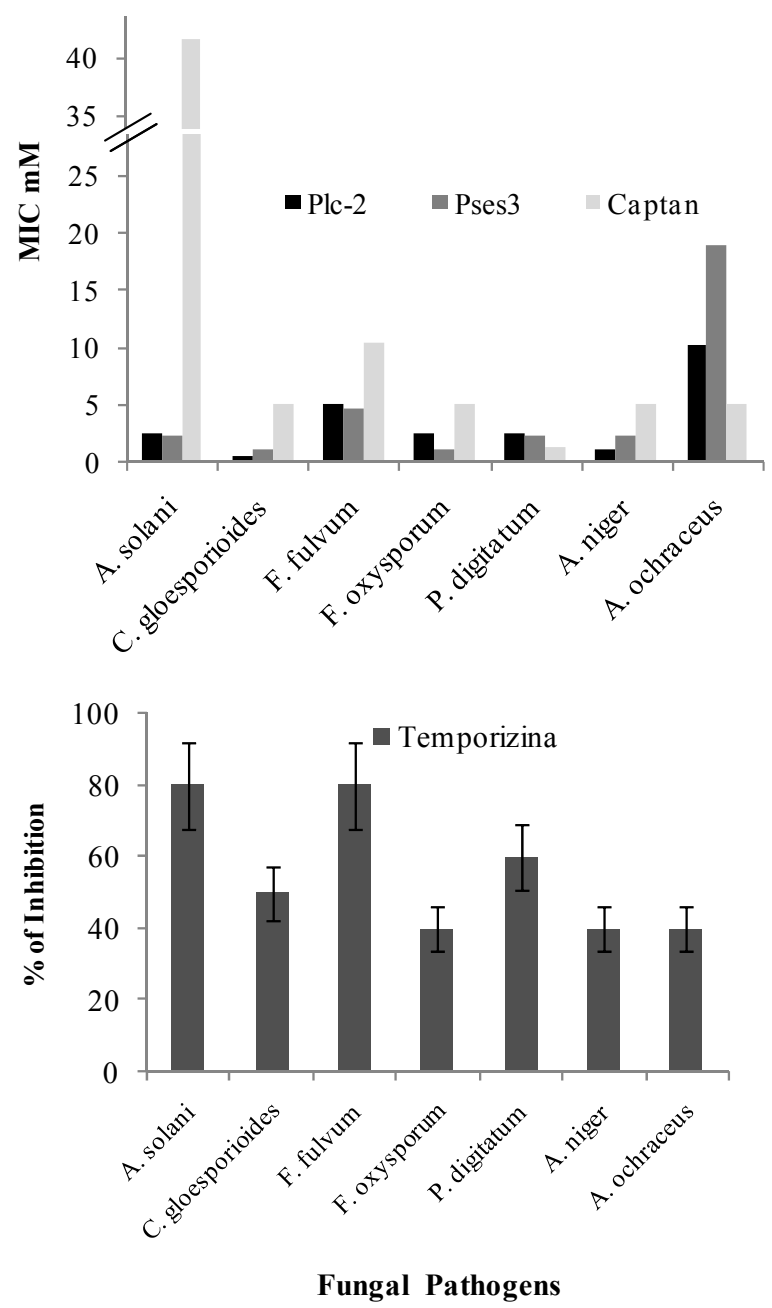

Figure 3. Effects of the treatments on the seven phylamentous fungi. Above: MIC ( $\mu \mathrm{M})$ of Plc-2, Pses3 and Captan observed for seven phytopathogens. Below: Inhibition growth observed on phylamentous fungi caused by Temporizina at $25.7 \mu \mathrm{M}$.

An outstanding result from the peptides studied was that the MIC values were always lower than Captan, the positive control (Table 4 and Figure 3), except for P. digitatum and A. ochraceus. For instance, for $A$. solani and C. gloesporioides, the MIC values obtained with Plc-2 were 16.3 and 8.1 times smaller compared to the commercial fungicide. Similarly, for the peptide Pses3 these values were 17.6 and 4.4 times smaller, respectively. However, in the case of $P$. digitatum and A. ochraceous, although they completely inhibited the growth of the fungus, their MIC values were larger than that of Captan (Table 4).

Another valuable finding was the observed MFC values, as mentioned above. In effect, fungicidal behaviors were observed for the peptides Plc-2 and Pses3. For these two peptides and for several of the fungi, MFC values were lower than $3 \mu \mathrm{M}$ (Table 4).

The seven fungi were subjected to concentrations of AMPs close to the MIC values for a given AMP-fungus combination and then examined by microscopy (Figure 4). The potential relationship between fungal growth inhibition and increased cell membrane permeability due to a given AMP was evaluated. Probe SG, in 
combination with probe CFW, allows determination of the membrane permeability state as described above.

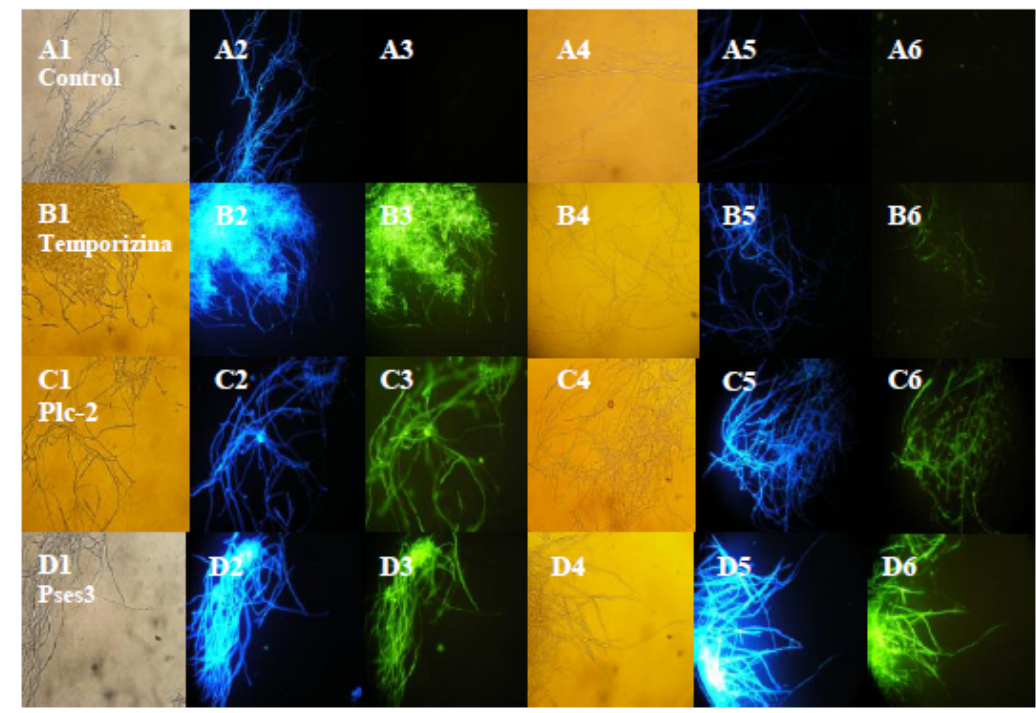

Figure 4. Microscopy visualization after $24 \mathrm{~h}$ of the mycelium of $C$. gloesporioides and $P$. digitatum treated with Temporizina, Plc-2, and Pses3. Images of the mycelium from a: Control, b: Temporizina 25.7 $\mu \mathrm{M}$, c: Plc-2 at MIC concentration, $0.64 \mu \mathrm{M}$ for $C$. gloesporioides and $2.56 \mu \mathrm{M}$ for P. digitatum, d: Pses 3 at MIC concentrations, $1.18 \mu \mathrm{M}$ for $C$. gloesporioides and $2.37 \mu \mathrm{M}$ for $P$. digitatum. Panels 1 to 3 and 4 to 6 respectively show the same area viewed in bright field (panels 1 and 4), CFW fluorescence (panels 2 and 5) and SG (Panels 3 and 6).

For Temporizina the values of inhibition varied between 40 and $80 \%$ (Figure 3) suggesting that this peptide has different behavior depending on the fungal species. As is known, the components of the external structures of the microorganisms (membrane and cell wall) are highly variable in composition depending on the species, probably affecting the fungicidal activity of the peptides.

When $C$. gloesporioides and $P$. digitatum were treated with Temporizina at concentrations that produce percentages of inhibition near 50\% and 60\% respectively (Figure 3), strong emission of SG fluorescence was amazingly observed, for these two fungi only. In fact, this might indicate that exposure to Temporizina permeates the fungal cell even at partially inhibitory concentrations (Figure 4). While the higher fungi were all imperfect and Deuteromycetes, the behavior of peptides was differential with different species, suggesting that the interaction depends on factors such as the composition of the wall or cell membrane (chitin content, sterols, glycoproteins, lipids, etc, Table 1). Plc-2 and Pses3 caused the permeation of the membrane of all fungal species treated at any concentration near to their MIC values (see Table 4 and Figure 4).

As noted above, many factors need to be investigated to determine the specific interactions between AMP and microorganism. It is widely accepted that the mode of action of Temporins and many of the cationic AMPs in bacteria is permeabilization of the plasma membrane with subsequent cell lysis (Bowman and Free, 2006). Nevertheless, other studies have indicated that cell permeation may not be part of a general mechanism leading to the lethal action of the peptide (Mangoni, 2006), and this is in accordance with our results. Temporizina shows high values of inhibitory activity in $A$. solani and $F$. fulvum without evidence of permeation as in $C$. gloesporioides and P. digitatum (data not shown).

Some authors reported alteration of the E. coli membrane at concentrations of Temporins below that of growth inhibition (Mangoni et al., 2004). This finding is consistent with our results for the species C. gloesporioides and P. digitatum where lipid composition seems to be a key factor for the activity (Turk et al., 1987, Wassef et al., 1985). Fungal species treated with Plc-2 and Pses 3 peptides resulted in $100 \%$ growth inhibition and low values of MIC and caused membrane disruption and high levels of fluorescence emission in all species using the SG probe (Table 4, Figure 4). This study using imperfect fungi and Deuteromycetes may complement previous efforts to determine what microorganisms are affected by Plc-2 as well as what types of mechanisms are likely to be involved. Many reviews indicate (Cole et al., 1997, Jung et al., 2007; Thevissen et al., 1999) that Pleurocidina, 
from which Plc-2 is derived, exerts antimicrobial activity mainly through intracellular targets in microorganisms such as Saccharomyces cerevisiae, Candida albicans, Malassezia furfur, Trichosporon beigelli, Staphylococcus aureus, Pseudomonas aeruginosa, and Klebsiella pneumoniae, without cellular permeation. In our study, for all the filamentous fungal species tested, inhibition was accompanied by cell permeabilization, leading to think that the mode of action in fungal species is specific and different from bacteria.

In Table 2, the structural parameters and properties data of the three antimicrobial peptides used in this study are shown. The peptides assayed in this study have positive net charge, with different hydrophobicity. Previous reports established a relationship between the cationic nature of peptides at physiological $\mathrm{pH}$ and their antimicrobial activity (Brogden, 2005; Jenssen et al., 2006). The cationic nature of many AMPs involves an electrostatic attraction to a cell surrounded by negative charge, as in the case of lipopolysaccharide (LPS) of Gram negative bacteria, or glycoproteins and glycosphingolipids of the fungal wall. In fact, this is a plausible reason for specificity against microorganisms and the absence of toxicity against animal and plant cells (Zasloff, 2002; Alves et al., 2010). Peptide hydrophobicity is another important parameter related to antimicrobial activity, and in our case it varied greatly among the peptides studied, being particularly high in the case of Plc- 2 .

The relationship between structure and function of each peptide must, in turn, be closely related to the characteristics of the microorganism to be controlled. Through biotechnological approaches, the AMPs are one of the most promising alternatives to chemical control. In fact, after the isolation of natural AMPs, the application of combinatorial chemistry allows synthetic peptides to be designed with more effective antimicrobial activities and with advantageous properties. These multifunctional molecules are likely to have a great future as new biotech molecular biocides.

In conclusion, this work compares peptides previously known for their antibacterial activity, for antifungal activity against seven phylamentous fungi isolated from plant tissue. Peptides Pses3 and Plc-2 showed remarkable antifungal activity in all tested fungi. Pses3, derived from sesame seeds, is a novel peptide, so far not reported in databases, with promising characteristics for use in the control of pathogens in the food industry.

\section{Acknowledgements}

This work received financial assistance from CNPq, DICyT-MEC, CAPES, FAPERJ-Fo SGS. We thank the peptide synthesis platform of the Center for Technological Development in Health (CDTS-PDTIS) of FIOCRUZ for the use of their facilities. We are grateful to our co-workers who supplied fungal isolates and provided useful suggestions and information for this study. Kind thanks to: Nora Altier (Department of Plant Protection, INIA Las Brujas), Elena Pérez (Department of Plant Pathology, INIA Salto Grande) and Fernando Rivas (National Citrus Production, INIA Salto Grande). We are grateful to Dr. José Francisco Marcos for his critical review of the manuscript.

\section{References}

Agrios, G. (2004). Fitopatología. D.F., México, LIMUSA.

Alves, C., Melo, M., Franquelim, H., Planas, M., Feliu, L., Bardají, E., ... Castanho, M. (2010). Escherichia coli cell surface perturbation and disruption induced by antimicrobial peptides BP100 and pepR. The Journal of Biological Chemistry, 285, 27536-27544. http://dx.doi.org/10.1074/jbc.M110.130955

Badosa, E., Ferré, R., Francés, F., Bardají, E., Feliu, L., Planas, M., \& Monetsinos, E. (2009). Sporicidal activity of synthetic antifungal undecapeptides and control of Penicillium rot of apples. Applied Envionmental Microbiology, 75, 5563-5569. http://dx.doi.org/10.1128/AEM.00711-09

Bowman, S., \& Free, S. (2006). The structure and synthesis of the fungal cell wall. BioEssay, 28, 799-808. http://dx.doi.org/10.1002/bies.20441

Broekaert, W. F., Terras, F. R. G., Cammue, B. P. A., \& Vanderleyden, J. (1990). An automated quantitative assay for fungal growth inhibition. FEMS Microbiology Letter, 69, 55-60. http://dx.doi.org/10.1111/j.1574-6968.1990.tb04174.x

Brogden, K. A. (2005). Antimicrobial peptides: Pore formers or metabolic inhibitors in bacteria? Nature Reviews Microbiology, 3, 238-250. http://dx.doi.org/10.1038/nrmicro1098

Bulet, P., Stöcklin, R. and Menin, L. (2004) Anti-microbial peptides from invertebrates to vertebrates. Immunogical Reviews 2004; 198: 169-184. http://dx.doi.org/ 10.1111/j.0105-2896.2004.0124.x

Cole, A., Weis, P., \& Diamond, G. (1997). Isollation and characerization of pleurocidin, an antimicrobial peptide in the skin secretions of winter fluonder. The Journal of Biological Chemistry, 272, 12008-12013. http://dx.doi.org/ 10.1074/jbc.272.18.12008 
Conlon, J. M., Kolodziejek, J., \& Nowotny, N. (2004). Antimicrobial peptides from ranid frogs: taxonomic and phylogenetic markers and a potential source of new therapeutic agents. Biochimica et Biophysca Acta, 1696, 1-14. http://dx.doi.org/10.1016/j.bbapap.2003.09.004

De Simone, S. G., \& Souza, A. L. A. (2002). Peptídeos microbicidas: Uma alternativa viável para a terapia antimicrobiana. Biotecnologia Ciência e Desenvolvimento, 24, 12-16.

Díaz-Dellavalle, P., Cabrera, A., Alem, D., Larrañaga, P., Ferreira, F., \& Dalla-Rizza, M. (2011) Antifungal activity of medicinal plant extracts against phytopathogenic fungi Alternaria sp. Chilean Journal of Agricultural Research, 71(2), 231-239.

EFSA Journal Annual Report on Pesticide Residues according to Article 32 of Regulation (EC) No 396/2005. 2010, 8(6), 1646. http://dx.doi:10.2903/j.efsa.2010.1646

Ghiselli, R., Giacometti, A., Cirioni, O., Mocchegiani, F., Orlando, F., Kamysz, W., ... Saba, V. (2002). Temporin A as a prophylactic agent against methicillin sodium-susceptible and methicillin sodium-resistant Staphylococcus epidermidis vascular graft infection. Journal of Vascular Surgery, 36, 1027-1030. http://dx.doi.org/ 10.1067/mva.2002.127530

Giangaspero, A., Sandri, L., \& Tossi, A. (2001). Amphipathic a helical antimicrobial peptides A systematic study of the effects of structural and physical properties on biological activity. European Journal of Biochemistry, 268, 5589-5600. http://dx.doi.org/ 10.1046/j.1432-1033.2001.02494.x

Hammami, R., Ben, H. J., Vergoten, G., \& Fliss, I. (2009). PhytAMP: a database dedicated to antimicrobial plant peptides. Nuclear Acids Research, 37, D963-D968. http://dx.doi.org/ 10.1093/nar/gkn655.

Hancock, R. E. W., \& Sahl, H. G. (2006). Antimicrobial and host-defense peptides as new anti-infective therapeutic strategies. Nature Biotechnology, 24, 1551-1557. http://dx.doi.org/ 10.1038/nbt1267

Jung, H. J., Park, Y., Sung, W. S., Suh, B. K., Lee, J., Hahm, K. S., \& Lee, D. G. (2007). Fungicidal effect of pleurocidin by membrane-active mechanism and design of enantiomeric analogue for proteolytic resistance. Biochimica et Biophysica Acta, 1768, 1400-1405. http://dx.doi.org/10.1016/j.bbamem.2007.02.024

Jenssen, H., Hamill, P., \& Hancock, R. E. W. (2006). Peptide Antimicrobial Agents. Clinical Microbiology Reviews, 19, 491-511. http://dx.doi.org/ 10.1128/CMR.00056-05

Mangoni, M., Papo, N., Barra, D., Simmaco, M., Bozzi, A., Di, G. A., \& Rinaldi, A. C. (2004). Effects of the antimicrobial peptide temporin L on cell morphology, membrane and viability of Escherichia coli. Biochemical Journal, 380, 859-865. http://dx.crossref.org/10.1042\%2FBJ20031975

Mangoni, M. (2006) Temporins, anti-infective peptides with expanding properties. Cellular and Molecular Life Sciences 63: 1060-1069. http://dx.doi.org/ 10.1007/s00018-005-5536-y.

Marcos, J. F., \& Gandía, M. (2009). Antimicrobial peptides: to membranes and beyond. Expert Opinion on Drug Discovery, 4, 659-671. http://dx.doi.org/10.1517/17460440902992888

Marcos, J. F., Muñoz, A, Pérez-Payá, E., Misra, S., \& López-García, B. (2008). Identification and racional design of novel antimicrobial peptides for plant protection. Annual Reviews of Phytopatholgy. 46, 273-301. http://dx.doi.org/10.1146/annurev.phyto.121307.094843

Muñoz, A., \& Marcos, J. F. (2006). Activity and mode of action against fungal phytopathogens of bovine lactoferricin-derived peptides. Journal of Applied Microbiology, 101, 1199-1207. http://dx.doi.org/10.1111/j.1365-2672.2006.03089.x

Muñoz, A., López-García, B., \& Marcos, J. F. (2006). Studies on the mode of action of the antifungal hexapeptide PAF26. Antimicrobial Agents and Chemotherapy, 50, 3847-3855. http://dx.doi.org/10.1111/j.1365-2672.2006.03089.x

Montesinos, E. (2007). Antimicrobial peptides and plant disease control. FEMS Microbiology Letters, 270, 1-11. http://dx.doi.org/ 10.1111/j.1574-6968.2007.00683.x

Oren, Z., Lerman, J. C., Gudmundsson, G. H., Agerberth, B., \& Shai, Y. (1999). Structure and organization of the human antimicrobial peptide LL-37 in phospholipid membranes: relevance to the molecular basis for its non-cell-selective activity. Biochemical Journal, 341, 501-513.

Patrzykat, A., Friedrich, C., Zhang, L., Mendoza, V., \& Hancock, R. E. W. (2002). Sublethal concentrations of pleurocidin-derived antimicrobial peptides inhibit macromolecular synthesis in Escherichia coli. Antimicrobial Agents and Chemotherapy, 605-614. 
http://dx.crossref.org/10.1128\%2FAAC.46.03.605-614.2002

Pelegrini, P. B., Del Sarto, R. P., Silva, O. N., Franco, O. L., \& Grossi-de-Sa, M. F. (2011). Antibacterial peptides from plants: What they are and how they probably work. Biochemistry Research International, 1-9. http://dx.crossref.org/10.1155\%2F2011\%2F250349

Satish, S., Mohana, D., Ranhavendra, M., \& Raveesha, K. (2007). Antifungal activity of some plant extracts against important seed borne pathogens of Aspergillus sp. Journal of Agricultural Technology, 3, 109-119.

Souza, A. L. A. (2012). Structural and Activity Study of Biocide Temporizina. A Hybrid Peptide with antiparasitic activity against Trypanosoma cruzi. Rio Janeiro, Brasil. PPGBP / FIOCRUZ- PhD Thesis Parasite Biology.

Souza, A. L. A., Díaz- Dellavalle P., Cabrera A., Larrañaga P., Dalla-Rizza M., \& De-Simone, G. S. Antimicrobial activity of pleurocidin is retained in plc-2, a c-terminal 12-aminoacid fragment. Peptides, (acepted for publication, July 2012).

Teles-Costa, F., Maria-Neto, S., Bloch, J., \& Luiz, F. C. (2007). Susceptibility of human pathogenic bacteria to antimicrobial peptides from Sesame kernels. Current Microbiology, 55, 162-166. http://dx.doi.org/10.1007/s00284-007-0131-0

Téllez, G., \& Castaño, J. (2010). Péptidos antimicrobianos. Infectio, 14, 55-67.

Thevissen, K., Terras, F., \& Broekaert, W. (1999). Permeabilization of fungal membranes by plant defensins inhibits fungal growth. Applied and Environmental Microbiology, 65, 5451-5458.

Turco, S., Hull, S., Orlandi, P., Shepherd, S. D., Homans, S. W., Dwek, R. A., \& Rademacher, T. W. (1987). Structure of the major carbohydrate fragment of the Leishmania donovani lipophosphoglycan. Biochemical Journal, 26, 6233-6238.

Wassef, M., Fioretti, T., \& Dwyer, D. (1985). Lipid analyses of isolated surface membranes of Leishmania donovani promastigotes. Lipids, 20, 108-115.

Zasloff, M., (2002). Antimicrobial peptides of multicellular organisms. Nature, 415, 389-395. http://dx.doi.org/10.1038/415389a

Zhao, H., Rinaldi, A. C., Di, G. A., Simmaco, M., \& Paavo-Kinnunen, K. (2002). Interactions of the antimicrobial peptides temporins with model biomembranes: comparison of temporins $\mathrm{B}$ and $\mathrm{L}$. Biochemestry, 41, 4425-4436. http://dx.doi.org/ 10.1021/bi011929e 